\title{
Interspecific competition in germination of bird-dispersed seeds in a habitat with sparse tree vegetation in South Africa
}

\author{
L. R. Vukeya ${ }^{2,3}$, T. M. Mokotjomela $a^{1,4^{*}}\left(\mathbb{0}\right.$, N. J. Malebo ${ }^{3}$ and S. Oke ${ }^{3}$
}

\begin{abstract}
Background: By transporting and scarifying the seeds during ingestion, avian frugivores reduce the competition with siblings, and may improve the germination which is critical for dispersal effectiveness and population recruitment. However, generally, there is limited knowledge on how deposited seeds interact/compete in the new microsite. We tested the hypothesis that the bird-dispersed seeds benefit from improved germination after their passage through the bird's gut; and we investigated the potential impact of seed density on competition at the microsites by determining whether seed density and species diversity influence germination in the Free State Province, South Africa.

Results: Overall, the results partly supported the hypothesis. Germination trials with defecated seeds of five plant species compared with the manually depulped seeds showed that only Searsia lancea had significantly higher seed germination success and improved germination speed after passage through the bird gut while Ziziphus mucronata only benefited rapid germination. There was a significant correlation between seed size and the germination of birdingested seeds except in Olea subsp. africana possibly due to possession of extremely hard protective seed cover. Seed competition experiments pointed to Z. mucronata and O. subsp. africana having significant germination performance that was positively correlated to seed density and seed size while Ehretia rigida did not germinate at all. Seed species diversity in the germination trays did not have a significant impact since the seeds of two former plant species consistently displayed significantly higher germination across the competition levels.

Conclusions: We conclude that different plant species respond differently to seed ingestion by birds, and that further long-term tests for germination physiological responses of the seeds' samples used in this study are required since poor germination observed in other tree/shrub species cannot be attributed to competition solely.
\end{abstract}

Keywords: Avian frugivory, Grasslands biome, Seeds, Bush encroachment, Conservation

\section{Background}

Seed dispersal is the movement of seeds away from their parent plants through a variety of dispersal vectors, either abiotic or biotic (Jones et al. 2017; Thomson et al. 2011; Wang and Smith 2002; Westcott and Graham

\footnotetext{
*Correspondence: mokotjomelat@yahoo.co.uk

${ }^{1}$ Centre for Invasion Biology, South Africa National Biodiversity Institute, Free State National Botanical Garden, Free State, Rayton, Dan Pienaar, Danhof, P.O Box 29036, Bloemfontein 9310, South Africa

Full list of author information is available at the end of the article
}

2000). Seeds in fleshy fruits (i.e., drupe) are dispersed or discarded, often after animals (e.g., birds) have consumed the soft edible portion of the fruit, called the mesocarp, and dispersed the ingested endocarp containing the seeds (Dardick and Callahan 2014). Seed dispersal is crucial in plant regeneration, since it promotes the maintenance of the genetic structure of many native plant species (Kleyheeg 2018; Egerer et al. 2018; Castilla et al. 2017; Howe 2016; Heleno et al. 2011). In addition, many native tree and shrub species require animal-mediated seed dispersal as a longevity strategy in response to environmental 
change (Howe 2016). Plants (i.e., angiosperms) interact with multiple mutualists in a network pattern to acquire a variety of ecological services (e.g., pollination and seed dispersal) (Jordano 2016; Mokotjomela et al. 2021; Thomas et al. 2007; Strauss and Irwin 2004). Avian frugivores have been consistently reported to be essential in shaping the seed dispersal pattern of native vegetation structures (Le Roux et al. 2020; Rehm et al. 2019; Trakhtenbrot et al. 2005; Jordano 2000). For example, Banos-villalba et al. (2017) reported that macaws dispersed $75 \%$ to $100 \%$ of seeds or fruits over ranges of up to $1200 \mathrm{~m}$, and influenced the recruitment success of some forest plant species, thus shaping the vegetation structure and function of the Amazonian ecosystem, Beni Savannas.

The effectiveness of seed dispersal is a product of the quality and quantity components of the multiple vertebrate vector species that consume fruits and seeds of different plant species in each habitat (Mokotjomela et al. 2016; Schupp et al. 2010; Schupp 1993). The germination of ingested seeds represents the quality component, which is regarded as more influential in plant recruitment than the quantity component (Mokotjomela et al. 2016; Schupp et al. 2010; Schupp 1993). Avian frugivores occasionally modify the rate of germination and enhance the chances of seeds' survival (Kleyheeg 2018; Mokotjomela et al. 2015, 2016; Thabethe et al. 2015; Fricke et al. 2013; Mokotjomela et al. 2021; Barnea et al. 1991). For example, Traveset et al. (2001) tested the germination characteristics of the seeds from different plants (Rhubus ulmifolius, Osyris alba, Rubia peregrine, Asparagus acutifolius, and Phillyrea spp) that passed through birds' guts in the western Mediterranean shrubland, and found that different germination speeds/rates were promoted by the treatment in the birds' gut. However, Alves-Costa and Eterovick (2007) investigated the seed/fruit trail of 53 species that were consumed and dispersed by coatis (Nasua nasua) in Mangabeiras Park, Southern Brazil, and found that the seeds' passage through the coatis' guts did not affect germination success, except for Myrcia guajavaefolia, which enjoyed a 50\% increase in germination success. Also, Dlamini et al. (2018) compared the effect of frugivorous birds on the seed dispersal and germination of two alien invasive plants (Schinus terebinthifolius and Listea glutinosa) in South Africa, and found that frugivorous birds enhance the germination rate of Schinus terebinthifolius after seed treatment, although no positive effect was noted on the germination of Listea glutinosa after seed treatment.

The dispersal of large numbers of seeds over long distances from their maternal plants reduces intra- and inter-species competition (Mokotjomela et al. 2013; Schurr et al. 2009; Higgins et al. 2003), and provides essential genetic links between disconnected plant populations (Schupp et al. 2010; Nathan et al. 2008). Long-distance dispersal also increases the chances of recruitment in the absence of seed predators by maximising the seeds' access to safe microsites (Howe 1986). In competitive conditions, the early dispersal of seed species leads to their occupation of safe microsites both above and below the ground, and consequently increases the species' recruitment success (Korner et al. 2007). Plant species that germinate early may have an advantage in survival and growth, due to having more space and greater access to resources (Guido et al. 2017). The interspecific competition between seeds may differ from year to year, depending on the availability of resources and weather conditions, as well seed density in the microsite.

There are other factors that can cause variation in the seed germination success and the rate, such as seed size (Mandal et al. 2008), the seed's endocarp (i.e., its hormones) (Negash 2010; Dalling et al. 2011; Bekele 2000), and the conditions where the seeds are deposited (Carlo and Tewksbury 2013; Hulme 1998). The size of the seed will interact with local abiotic conditions and other codeposited seeds to influence germination. Studies have shown that plant species with large seeds have greater success in their germination rate, and a positive effect on the seedling's survival than the small seeds (Kolodziejek 2017; Souza et al. 2014; Mandal et al. 2008; Kahmen and Poschlod 2008; Cordazzo 2002). Mandal et al. (2008) consistently found that variation in seed size influences the germination, after recording a 78\% germination success for the large seeds of Hyptis suaveolens, while smaller seeds had a $41 \%$ of germination success. However, Moles and Westoby (2004) found no correlation between seed mass and the species' germination of viable seeds. The seed endocarp provides physical protection against disease (Dardick and Callahan 2014), but conversely it is a barrier to the germination success (Negash 2010; Bekele 2000). For example, Negash (2010) and Cuneo et al. (2010) found that the hardened endocarp of Olea europaea subsp. africana reduced rapid germination by blocking moisture and oxygen from reaching the seed.

Seed germination success can be affected by among other factors, the competitive interactions between species as well as their density in the microsite (Orrock and Christopher 2010); and thus influence the ultimate individual plant species' population fitness (Goets et al., 2018; Aschehoug et al. 2016; Johnson et al. 2008; Schupp 1993). It has been suggested that seeds of different species can sense each other prior to their emergence and shift their germination timing to ovoid competition (Ward 2016; Tielborger and Prasse 2009; Wang and Smith 2002). Depending on the species, seed germination may be either delayed or accelerated as a competitive strategy against the neighbouring seeds (Bergelson 
and Perry 1989; Lortie and Turkington 2002; Orrock and Christopher 2010; Turkington et al. 2005). Consistently, Orrock and Christopher (2010) observed an accelerated seed germination response in Phytolacca americana during situation of high seed density. It has been shown that the seeds endocarp of certain species modulates germination time using physiological mechanisms controlled by hormones that regulate seed dormancy and protect the embryo against pathogens by releasing the phenolic compounds (i.e., tannins) (see Raviv et al. 2017). In some cases, the released endocarp hormones can also suppress the germination of neighbouring seeds (Miransari and Smith 2014). Lortie and Turkington (2002) tested the effect of initial seed density on the structure of a desert annual plant community over three years. The results shown that emergence of seedlings was significantly influenced by initial seed density in all three years, with higher initial seed densities having lower rates of emergence (Lortie and Turkington 2002).

While it is relatively well-known how seeds are affected by passage through the gut and the associated variable retention times (Le Roux et al. 2020; Mokotjomela et al. 2015; Mokotjomela et al. 2021; Traveset et al. 2001), how post-dispersal seed predation affects recruitment (Hulme et al. 1998), and how scatter-hoarding also benefits species recruitment (Vander Wall and Beck 2012), limited attention has been given to how the seeds of different plant species that either remain at the deposition location or survive post-dispersal predation interact to complete the recruitment processes. Hulme (1998) argued that both variation in post-dispersal seed predation and differences in predation between plant species are important elements that facilitate the coexistence of different plant species, and at the same time seed predation directly influences competition for these microsites. We therefore postulated that, in areas where perching material for birds is rare-such as the grasslands-dominated habitats of the Free State Province, South Africa-seeds dispersed by birds accumulate in the areas they frequent most, thereby increasing the possibility of density-dependent competition-which, however, must be minimised by the long-distance dispersal of seeds. Studies have shown that the distribution of perching material, as well as selective fruit foraging by birds, influences the patterns of seed deposition (Aukema and Rio 2002; Howe 1986; Stiles and White 1986), with the perching points, and the most preferred fruiting plants receive large numbers of seeds (Carlo and Tewksbury 2013). In view of these, we tested the hypothesis that bird-dispersed seeds benefit from improved germination after their passage through the bird's gut; and we investigated the potential impact of seed density on competition at microsites, determining whether species diversity influence competition with a focus on the fruit-bearing and avian-dispersed species of tree/shrubs in the Free State Province, South Africa.

\section{Methods and materials Study site}

The study was conducted in the Free State National Botanical Garden (FSNBG) (S 29 $12^{\prime} 55.6^{\prime \prime}$; E 26 $16^{\circ}$ 41,3"), Free State Province, South Africa (Fig. 1). The FSNBG covers an area of 66 hectares and is at an altitude between 1300 and $1400 \mathrm{~m}$ above sea level (Masilo 1999; Chaplin 1979). The vegetation structure is largely characterised by Bloemfontein Karroid Shrubland, Bloemfontein Dry Grassland, Winburg Grassy Shrubland, and Waterbody/Riparian vegetation (Mucina and Rutherford 2006). The FSNBG experiences a severe continental climate, with minimum winter temperatures below $0{ }^{\circ} \mathrm{C}$, the night temperature often below freezing, and frost in July. Fairly high summer temperatures frequently range between $30{ }^{\circ} \mathrm{C}$ and $35{ }^{\circ} \mathrm{C}$ in January (Haddad et al. 2019; Neethling and Haddad 2013). The mean annual rainfall is relatively low ( $584 \mathrm{~mm}$ annually), with most of rainfall being recorded during the summer months and in early autumn.

\section{Seed collection and seed viability test}

Seeds were collected on weekly bases during dry weather from various identified bird roosting areas (i.e., 17 locations) within FSNBG from March 2019 to February 2020. Only seeds that had been ingested and treated (i.e., that had passed through frugivorous birds' gut and been trapped in the faecal samples) were collected. The seeds, which were free from insects and diseases, were stored in paper bags in a seed storeroom before the individual seed-counting and germination trials. We used the seeds' structure (size, shape, coat, length, and width) to identify the different seeds (Ulian et al. 2019). For small seeds, we used the portable pocket $100 \times$ metal mini science microscope to identify each seed (Song et al. 2018). However, since moisture can disturb seed weight measurements, a digital calliper was also used to measure the length of each seed per species (i.e., 30 replicates) as a surrogate measure size.

Seed viability can be tested using the tetrazolium method, which was recommended by Van der Walt and Witkowski (2017) after applying it for a quick estimation of seed viability and vigour for Adenium swazicum in the Skukuza indigenous nursery, Kruger National Park. The tetrazolium test indirectly determines the respiratory activities in the cell found in the seed tissues (Franca-Neto and Krzyzanowski 2019). It is recommended that at least 100 seeds should be tested in replicates of 50 or less to increase the accuracy (Patil and Dadlani 2009; Delouche 1961). Due to the limited 


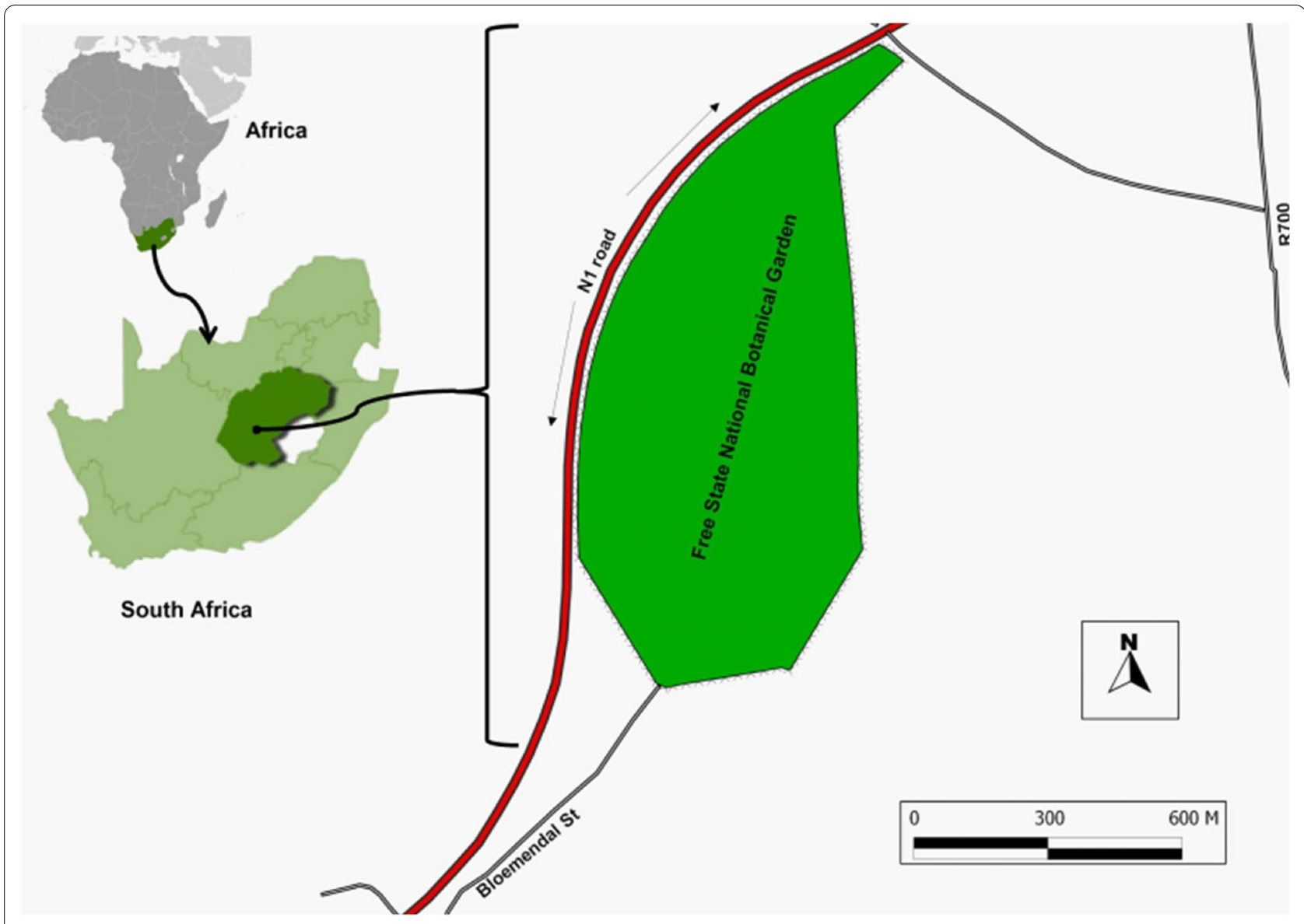

Fig. 1 Location of the study area: Free State National Botanical Garden, Bloemfontein in South Africa

number of seeds, we did not experimentally test seed viability, but used the published results for similar species in South Africa.

The seeds of all the four species and the extra species were viable in various ways (Table 1). Two tree/ shrub species, Ziziphus mucronata and Searsia lancea, displayed a viability of above $50 \%$, while the other tree/ shrub species (Olea europaea subsp. africana, Grewia occidentalis, and Ehretia rigida) had a seed viability that ranged from 8 to $45 \%$.
Ziziphus mucronata is a small to medium shrub that fruit a shiny reddish to yellowish brown spherical drupe when ripe (March-august) with sub-globose of up to $36 \mathrm{~mm}$ in diameter (Van Wyk and Van Wyk 2013). The ripe fruits are edible and has a stony endocarp with seeds that usually solitary, elliptic, and compressed (Hassen et al. 2005).

Searsia lancea is a small to medium, hardy, frost- and drought-resistant evergreen tree that grow up to $7 \mathrm{~m}$ in height usually with single-stemmed (Van Wyk and Van

Table 1 Seed viability (\%) of different tree/shrub species that were included in the germination trials in this study

\begin{tabular}{|c|c|c|c|c|c|}
\hline Species & Family & Seed viability \% & Study area/country & Natural/ treated seeds & Source \\
\hline Ziziphus mucronata & Rhamnaceae & $71-100 \%$ & South Africa & Natural & Weiersbye and Witkowski, 2002 \\
\hline Olea europaea subsp. africana & Oleaceae & $32-39 \%$ & South Africa & Natural & Mokotjomela et al. (2021) \\
\hline${ }^{*}$ Grewia flava (c. G. occidentalis) & Malvaceae & $29 \%$ & South Africa & Natural & Weiersbye and Witkowski, 2002 \\
\hline Ehretia rigida & Boraginaceae & $8-45 \%$ & South Africa & Natural but sterilised & Wilman et al., 2014 \\
\hline Searsia lancea & Anacardiaceae & $40-76 \%$ & South Africa & Natural & Weiersbye and Witkowski, 2002 \\
\hline
\end{tabular}


Wyk 2013). The species' fruits are slightly flattened, shiny spheroidal drupes of up to $5 \mathrm{~mm}$ in diameter that turns dull yellow to brown when ripe (Van Wyk and Van Wyk 2013), with the seed enclosed in an anacardium-type endocarp (Wannan and Quinn 1990).

Olea europaea subsp. africana is a small to medium evergreen tree which is drought- and frost-resistant and grow up to $12 \mathrm{~m}$ in height (Van Wyk and Van Wyk 2013). This species produces a small ovoid drupe fruit with spherical, thinly fleshy pulp which ripen purple-black (March-July), and seeds are indehiscent, stony, with hard endocarp (Cuneo et al. 2010).

Grewia occidentalis is a scrambling deciduous shrub that grow up to $3 \mathrm{~m}$ in height (Van Wyk and Van Wyk 2013). This species fruits (i.e., up to $1.5 \mathrm{~cm}$ wide) an edible distinctive four-lobed fruits common know as crossberry or four-corner that turns shiny reddish-brown when ripe (January-May) with the seed enclosed in a pyrene stony endocarp (Van Wyk and Van Wyk 2013).

Ehretia rigida is a deciduous small, hardy and drought resistant shrub usually multi-stemmed that grow up to $9 \mathrm{~m}$ in height (Van Wyk and Van Wyk 2013). The species fruit a round edible fruit with orange to red, turning black when ripe and has a kidney shaped seed that is about $3 \mathrm{~mm}$ long (Retief and Van Wyk 2001).

\section{Seed germination success: ingested seed vs depulped seeds}

One of the study's hypotheses was that frugivorous birds modify the rate of seed germination for seeds ingested during foraging (Mokotjomela et al. 2015, 2016). To study the impact of birds' ingestion of seeds on the germination success for plant species, we conducted seed germination trials, using the seed of four dominant native tree/shrub species: Z. mucronata, O. subsp. africana, S. lancea, and $E$ rigida, whose seeds had passed through the gut of frugivorous birds. We also used manually depulped seeds of the same tree/shrub species as experimental control. All the ingested seeds were collected from the 17 birds' roosting areas in the FSNBG.

We did not have appropriate infrastructure for keeping trapped birds for feeding trials in captivity, and thus research ethics could not endorse bird trapping. The surveillance digital camera traps (Uway VH200B), which are considered nonintrusive method of sample wildlife activities (Kays et al. 2011; Mokotjomela and Hoffmann 2013) were used to document bird species that defecated ingested seeds in different roosting sites during the peak fruiting time. Camera traps were set up following the bird foraging activity pattern: at sunrise (6h00), and monitoring at noon (12h00), and reset at $15 \mathrm{~h} 00$ for afternoon. At sunset (18h00), image data was downloaded from cameras and occasionally, they were left in attempt to determine the nocturnal mammals that might provide secondary seed dispersal services to the deposited seeds.

The three bird species namely: Olive thrush (Turdus olivaceus) ( $3.8 \pm 0.8 ; \mathrm{N}=156$; Fig. 2 iv), followed by the Cape robin-chat (Cossypha caffra) $(1.4 \pm 0.5 ; \mathrm{N}=156$; Fig. 2 vi), and Speckled mousebird (Colius striatus) $(1.0 \pm 0.4 ; \mathrm{N}=156 ;$ Fig. $2 \mathrm{v})$ displayed highest daily visitation frequency.

For depulped seeds, ripe and fleshly fruits were harvested directly from four native tree/shrub species. All the fruits from the four plant species were soft and moist; the seeds' chaff was rubbed off in water by hand, except for the fruits of $Z$. mucronata, for which a wire mesh screen was used: the fruit was rubbed off the seeds by moving them back and forth against the screen. A total of 100 seeds per plant species (50 ingested seeds and 50 depulped seeds) were used for the germination trials.

Before sowing the seeds, the trays were washed with household bleach to sterilise them against fungal attack and insect pests (Ulian et al. 2019; Mokotjomela et al. 2015). Forty trays were washed and placed in the sun to dry for a week before sowing (Nichols 2005). Each tray's dimension was $16 \mathrm{~cm} \times 14 \mathrm{~cm} \times 4.5 \mathrm{~cm}$; and each had drainage holes. The seeds were sown in the trays using $30 \mathrm{dm}^{3}$ of potting soil, comprising milled pine bark, black loam, coarse river sand, and coconut palm fibre without any other components. Potting soil is a free-draining mixture that can hold moisture for the seed germination process to start (Nichols 2005). The potting soil was mixed with water to make it moist before it was placed in the trays. The seeds were sown at least $1-1.5 \mathrm{~cm}$ deep from the top of the tray to allow enough room during watering, and 2-4 cm apart, depending on the species (Ulian et al. 2019). For each plant species, 10 ingested seeds (for the treatment) and 10 manually depulped seeds (for experimental control) were sown in different trays, and each tray was replicated five times. Cotyledon emergence was recorded as successful germination on a daily basis, and the number of seedlings that emerged in each germination tray was recorded. Irrigation was done as necessary, either in the mornings before $10 \mathrm{~h} 00$, or later, after $17 \mathrm{~h} 00$. The seed germination trials were monitored over a period of at least 3 months, from November 2019 to the end of March 2020, to allow for possible delays in the seed germination of other species.

The study also hypothesised that variations in seed size (i.e., their weight and length) may influence their successful germination, with large seeds having a greater germination success than smaller seeds (see Souza et al. 2014; Mandal et al. 2008; Kahmen and Poschlod 2008; Cordazzo 2002). Therefore, the seed size of different tree/shrub species was measured. Because some seeds were too small for the scale, twenty 


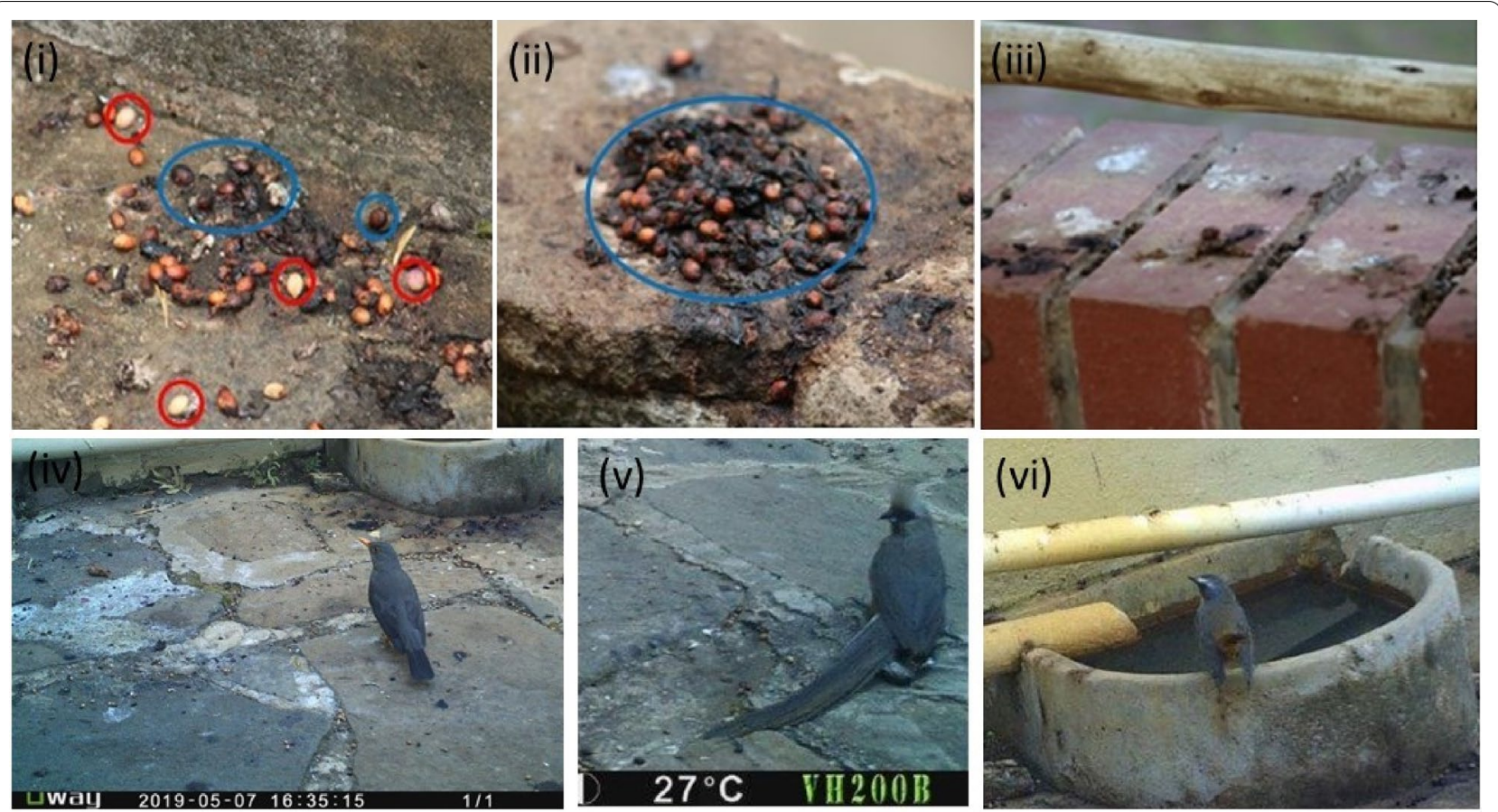

Fig. 2 Birds roosting areas: faecal samples were collected during the study (i-iii). Red circle shows regurgitated seeds and blue circle shows defecated seeds. Common bird species that ingested and defecated intact seeds included (iv) olive thrush Turdus olivaceus, (v) speckled mousebird Colius striatus and (vi) cape robin-chat Cossypha caffra recorded in one roosting site in the study area

seeds of each plant species were randomly selected and had their weight measured using a SWAN series digital scale in grams, which was replicated 30 times. Each measure of weight for 20 seeds was divided by the total number of seeds (i.e., 20) to get the weight of a single seed. Also, since moisture can confound seed weight, 30 seeds had their length as a surrogate measure of size measured using a digital calliper (i.e., the longitudinal dimension of each seed) for each plant species (Kleyheeg et al. 2018). Environmental conditions where seeds were collected, and the seed storage time had minimal impact on the results since almost all faecal samples was collected from dry surfaces and all seeds were sown within minimal dormancy time threshold (Table 2).

Germination speed is described as the of total number of the seedlings that emerged per time (Ranal and de Santana 2006; Maguire 1962). The seed germination speed was calculated as a ratio of the number of seedlings that germinated to the total number of days from sowing

Table 2 Seeds attributes for different tree/shrubs that were included in the germination trails

\begin{tabular}{|c|c|c|c|c|}
\hline \multirow[t]{2}{*}{ Species } & \multirow[t]{2}{*}{ Family } & \multicolumn{2}{|c|}{ Mean seed size \pm standard error } & \multirow[t]{2}{*}{ Seed viability storage period (source) } \\
\hline & & Seed length (mm) & Seed weight (g) & \\
\hline Ziziphus mucronata & Rhamnaceae & $8.72 \pm 0.13 \mathrm{~mm}$ & $0.19 \pm 0.004 \mathrm{~g}$ & $\begin{array}{l}\text { Seed viability improved with an age up to } 1 \text { year in the dry stor- } \\
\text { age (Weiersbye and Witkowski, 2002) }\end{array}$ \\
\hline Olea europaea subsp. africana & Oleaceae & $7.61 \pm 0.14 \mathrm{~mm}$ & $0.09 \pm 0.003 \mathrm{~g}$ & $\begin{array}{l}\text { Improves seed germination after being stored for } 3 \text { year (Fabbr } \\
\text { et al., 2004) }\end{array}$ \\
\hline Grewia occidentalis & Malvaceae & $4.71 \pm 0.13 \mathrm{~mm}$ & $0.04 \pm 0.002 \mathrm{~g}$ & $\begin{array}{l}\text { *Grewia bicolor (c. G. occidentalis), seed can be stored up to } \\
1 \text { year before sowing (Heuzé et al., 2015) }\end{array}$ \\
\hline Ehretia rigida & Boraginaceae & $3.52 \pm 0.10 \mathrm{~mm}$ & $0.03 \pm 0.007 \mathrm{~g}$ & $\begin{array}{l}\text { ** Ehretia cymosa (c. E. rigida) seed can be stored up to } \\
12 \text { months (Angaine et al., 2020) }\end{array}$ \\
\hline Searsia lancea & Anacardiaceae & $4.21 \pm 0.05 \mathrm{~mm}$ & $0.02 \pm 0.001 \mathrm{~g}$ & $\begin{array}{l}\text { Seed viability persist for up to } 1 \text { year (Weiersbye and Witkowski } \\
\text { 2002) }\end{array}$ \\
\hline
\end{tabular}

**Seed storage period of same genus was used 
date to the termination of the germination trial (Mokotjomela et al. 2016).

\section{Interspecific seed competition across different densities between plant species}

In this experiment, we investigated the competitive interactions during germination among seeds deposited by avian frugivores for five tree/shrub species that are likely to compete for dispersers' vectors (i.e., birds): Z. mucronata, O. subsp. africana, G. occidentalis (seeds dispersed between March to July), and S. lancea and E. rigida (seeds dispersed between August and December). The hypothesis tested in this experiment was that the germination of bird-dispersed seed is free from competition near the maternal plant, and thus germinates much better than undispersed seeds. The bird-ingested seeds were sown in the trays (size: $16 \mathrm{~cm} \times 16 \mathrm{~cm} \times 4.5 \mathrm{~cm}$ ), which were filled with potting soil and had drainage holes in the bottom. The seeds of each tree/shrub species were spread randomly in the trays and covered with a $1 \mathrm{~cm}$ layer of potting soil to mimic natural conditions (Nichols 2005). Species that were dispersed first (i.e., from March to July), were tested against each other first on the assumption that they would be the first to reach the microsite; and they were followed by two species that were dispersed between September and December. Since Z. mucronata displayed the highest level of germination in the first trials when testing the impact of passage through the gut, it was used as the reference species, and all the other species were added in decreasing order of seed size. Six replicates of each density set-up were sown: these entailed the low-density treatment of five seeds per species through to the high-density treatment of 20 seeds per species in each tray. Competing species (in groups of two, three, four, and five tree species) were sown according to four density classes at the same time: (1) six replicates of one container with five seeds per tree/shrub species; (2) six replicates of one container with ten seeds per tree/ shrub species; (3) six replicates of one container with 15 seeds per tree/shrub species; and lastly, (4) six replicates of one container with 20 seeds per individual species. The seedlings' emergence was recorded on a daily basis, and the number of seedlings in each tray was counted. Seed germination trials were monitored over a period of four months, from 22 November 2019 to 30 March 2020.

\section{Statistical analyses}

\section{Germination trials: bird-ingested vs depulped seeds}

To compare the germination rates between the birdingested seeds and the manually depulped seeds, the experimental design was balanced, with equal numbers of seeds in each tray. To test the hypothesis on the impact of the treatment of seeds during their passage through birds' gut, the germination rate of the bird-ingested seeds was compared with that of the manually depulped seeds (i.e., the experimental control). The generalised linear model analysis of variance (GLM-ANOVA) with negative binomial was applied to determine the significant differences in the seed germinated for each tree/shrub species and treatments. The dependent variable consisted of the count of the number of seeds germinated, while the treatments (i.e., the bird-ingested and the depulped seeds) and the tree/shrub species were defined as predictor variables. The Statistical Package for Social Sciences (SPSS, version 20) software was used to perform the analyses.

Spearman's correlation was used to test for significant correlation between germination rate and seed size-i.e., length.

Since the daily germination counts lead zero-inflated count data, the weekly counts of germinated seeds were used to estimate the germination speed for the depulped and ingested seeds per tree/shrub plant species. The cumulative weekly germination data was plotted to generate the germination speed curves per plant species.

\section{Interspecific competition for germination of bird-ingested seeds among tree/shrub species}

The seedling counts data were obtained from the balanced experimental design and we ran the comparisons of the seed germination for the different tree/shrub species across the different seed density levels and in the different combinations of tree/shrubs species per tray. Seedling counts data for competition level 1, was tested for normality using Shapiro-Wilk test $(\mathrm{SW}=0.844$, $\mathrm{N}=49, P=0.0001$ ) since sample size was less than 50 (Zar 2010). To reduce the inequality of variance, the germination counts were $\log$ transformed prior statistical analyses. Due to the complexity of the experimental design, a General Linear Model-Factorial Analysis of Variance was applied to determine the significant differences in seed germination at different seed density levels and number of species (species diversity) using SPSS Version 20. The response variable consisted of the counts of the germinated seeds. The tree/shrub species and the seed density levels were defined as the predictor variables in order to allow an assessment of the interactions between the different combinations of plant species and the seed density per unit area. The Tukey HSD test was used to separate significantly different means at $\mathrm{P} \leq 0.05$. The same procedure was used to analyse data for other competition levels 2,3 and 4 .

Furthermore, for any tree/shrub species that showed significant difference during any competition level, an overall analysis was run to compare how the germination rate varied between different seed density using the nonparametric model Kruskal-Wallis test. Also, we 
determined if the germination rate has relationship with total numbers of seeds per tray using the Spearman rank order correlation.

\section{Germination of Z. mucronata and O. subsp. africana across the seed density levels}

A nonparametric Kruskal-Wallis ANOVA was applied to compare the bird-ingested seed germination rate of $Z$. mucronata and O. subsp. africana across the different seed densities levels. The multi-comparison test distinguished different seed germination rates among the different seed density levels. Also, we tested for a correlation between germinated seeds of both plant species: $Z$. mucronata and O. subsp. africana and seed density (the total numbers of seeds per tray) to determine whether there was any relationship.

\section{Results}

\section{Germination trials: bird-ingested vs manually depulped seeds}

The comparisons of the germination rate between the bird-ingested and the manually depulped seeds were highly significant for the tree/shrub species (Wald $X^{2}=142.9, \mathrm{df}=3, P<0.001$; Fig. 3). $Z$. mucronata had the highest germination rate for its seedlings (mean $\pm \mathrm{SE}$ :
$60.0 \pm 8.0 \% ; \mathrm{N}=20$ ) (Wald $\left.\chi^{2}=55.0, \mathrm{df}=5, P<0.001\right)$, but bird-ingestion did not improve seed germination (Wald $X^{2}=1.4, \mathrm{df}=1, P=0.226$; Fig. 3 ). However, there were significant interactions between the seed germination of the different tree/shrub species and the seed treatments (Wald $\mathrm{X}^{2}=14.1, \mathrm{df}=3, \mathrm{p}=0.003$; Fig. 3), with S. lancea having a much more significant germination rate for the bird-ingested seeds than for the manually depulped seeds (Wald $X^{2}=12.7, \mathrm{df}=1, P=0.001$; Fig. 3B; Mean \pm SE: $56.0 \pm 5.0 ; \mathrm{N}=50$ vs $14.0 \pm 2.0 ; \mathrm{N}=50$ ). The Turkey posthoc test showed that there were no significant differences between the germination of the bird-ingested seeds and the depulped seeds of O. subsp. africana (Wald $X^{2}=1.1$, $\mathrm{df}=1, P=0.288$; Fig. 3), and E. rigida (Wald $\chi^{2}=0.3$, $\mathrm{df}=1, P=0.619$; Fig. 3 ).

Searsia lancea also had the seed germination speed improved significantly after passage through the bird gut (5.60 vs 1.44: Fig. 3B). Although Z. mucronata seed germinated was not improved by passage through the bird gut, the germination speed of ingested seeds was significantly improved (8.33 vs 4.69: Fig. 3A).

There was a significant correlation between seed size and the germination of bird-ingested seeds (Spearman Rank Order Correlation: $\mathrm{r}=0.30 ; \mathrm{N}=640 ; P<0.001$ ), with the tree/shrub species that have large seeds having

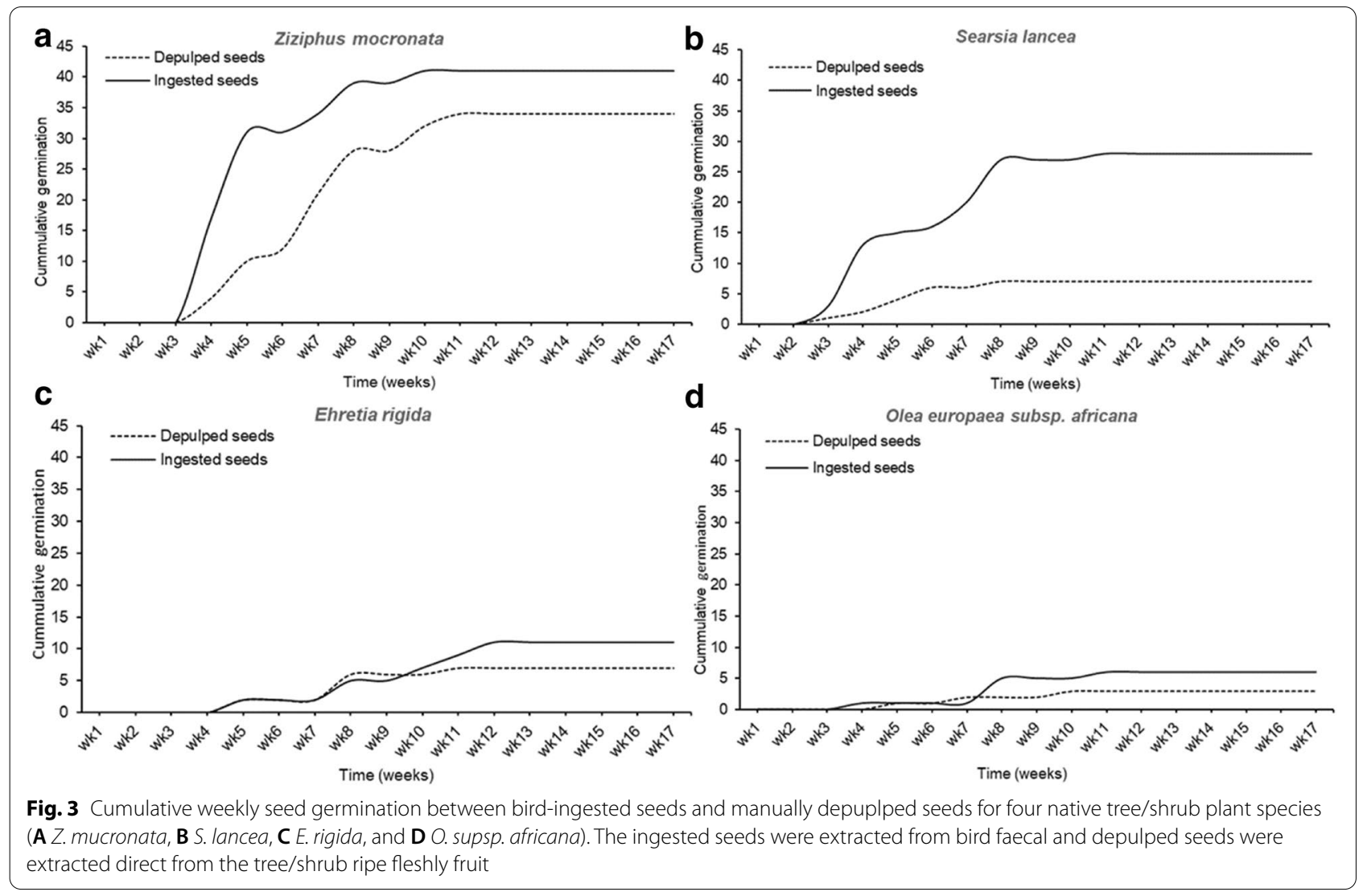


a greater germination than species with smaller seedsexcept for O. subsp. africana.

\section{Interspecific competition for germination of bird-ingested seeds among tree/shrub species}

(i) Level 1 competition test: two species (Z. mucronata and O. subsp. africana)

The comparison of the bird-ingested seed germination between two competing tree/shrub species, $Z$. mucronata (mean \pm SE: $48.9 \pm 7.1 \% ; \mathrm{N}=100$ ), and O. subsp. africana $(11.8 \pm 4.8 \%)$, was highly significant $\left(\mathrm{F}_{(1,40)}=42.4 ; \mathrm{p}<0.001\right.$; Fig. 4). Similarly, different levels of seed density were significantly different in the seed germination of those two competing shrubs species $\left(\mathrm{F}_{(3,40)}=3.3, \mathrm{p}=0.030\right.$; Fig. 4). Significant interactions were observed between the seed density and the seed germination for the different tree/shrub species $\left(\mathrm{F}_{(3,40)}=8.0\right.$, $\mathrm{p}=0.0003$; Fig. 4), with $Z$. mucronata showing a significantly higher seed germination than $O$. subsp. africana across three seed density levels-at seed densities of 10 (86.7 $\pm 4.2 \%), 20$ (43.3 $\pm 14.8 \%)$, and $30(55.6 \pm 7.4 \%)$ - but not at a seed density of $40(10.0 \pm 1.8 \%)$

(ii) Level 2 competition test: three tree/shrub species (Z. mucronata, G. occidentalis, and O. subsp. africana)
The comparisons of the bird-ingested seed germination rate among three competing tree/shrub speciesZ. mucronata (mean \pm SE: $49.2 \pm 9.3 \%$; $\mathrm{N}=150$ ), O. subsp. africana (17.8 $\pm 3.9 \%)$, and G. occidentalis $(12.9 \pm 5.2 \%)$ was highly significant $\left(F_{(2,60)}=36.2\right.$; $\mathrm{p}<0.001$; Fig. 5). The Tukey HSD test showed that, while the germination rate for $Z$. mucronata was significantly high, the latter two tree/shrub species had equivalent germination rates. Also, there were significant differences in the seed germination of the tree/shrub species across the different seed density levels $\left(\mathrm{F}_{(3,60)}=4.7 ; \mathrm{p}=0.054\right.$; Fig. 5). There were no significant interactions between the seed germination of the different tree/shrub species with the sown seed density levels $\left(\mathrm{F}_{(6,60)}=1.6\right.$; $\mathrm{p}=0.153$; Fig. 5), with $Z$. mucronata showing a higher germination than the other tree/shrub species across all seed densities: 15 (77.3 $\pm 16.9 \%) ; 30$ $(66.7 \pm 12.8 \%) ; 45(33.3 \pm 4.9 \%)$ and 60 (23.3 $42.9 \%$; Fig. 5).

(iii) Level 3 competition: four tree/shrub species $(Z$. mucronata, G. occidentalis, S. lancea, and O. subsp. africana)

The comparisons of the bird-ingested seed germination rates among four competing tree/shrub species - Z. mucronata (mean \pm SE: 59.9 $\pm 10.3 \%$; $\mathrm{N}=200)$, S. lancea (23.3 $\pm 6.9 \%)$, G. occidentalis

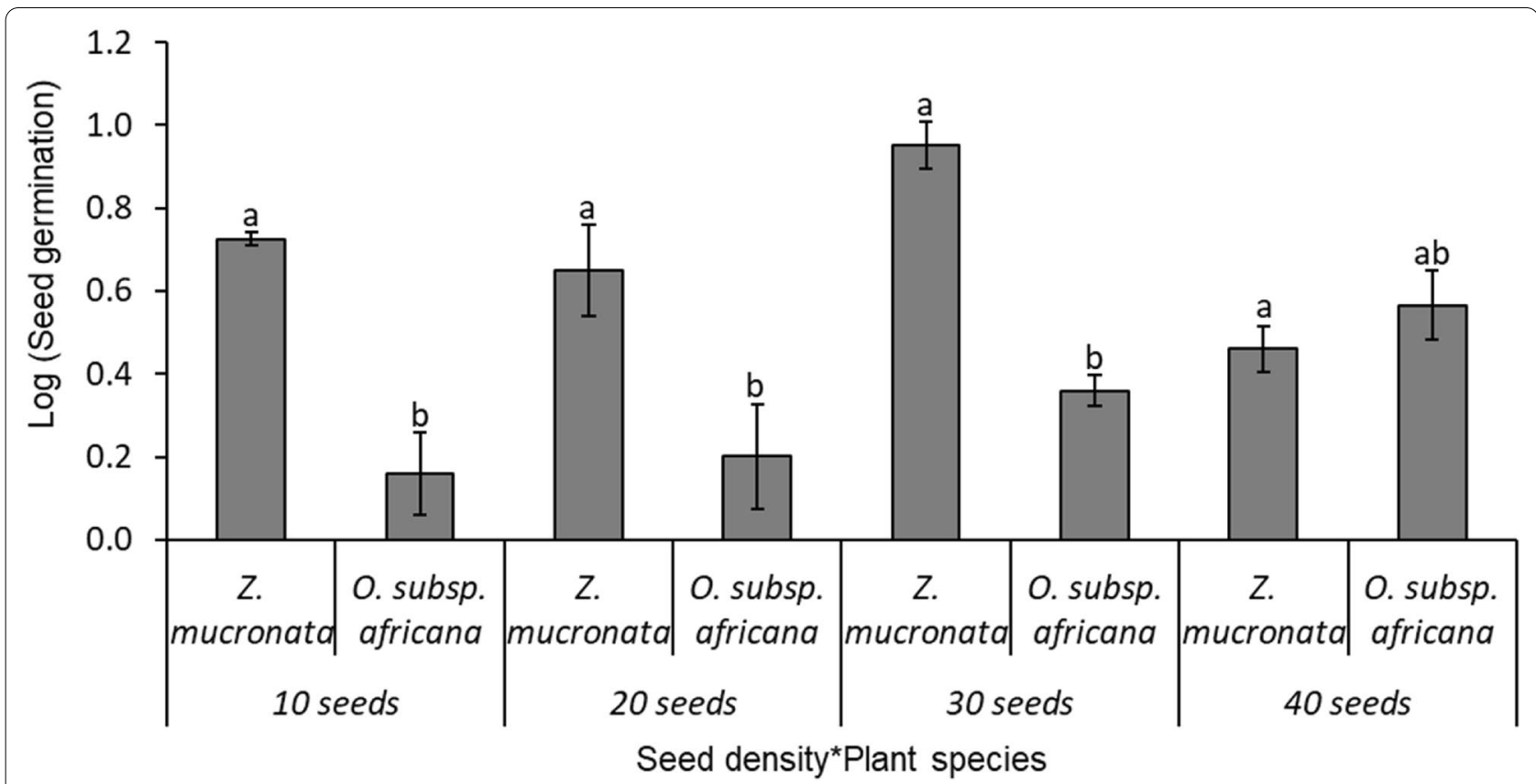

Fig. 4 Mean seed germination for different plant species in competition level 1 between two tree/shrub species: Z. mucronata and O. subsp. africana. The error bars represent the standard error of sample mean, and different letters above standard error bar denote significant differences between seed density levels 


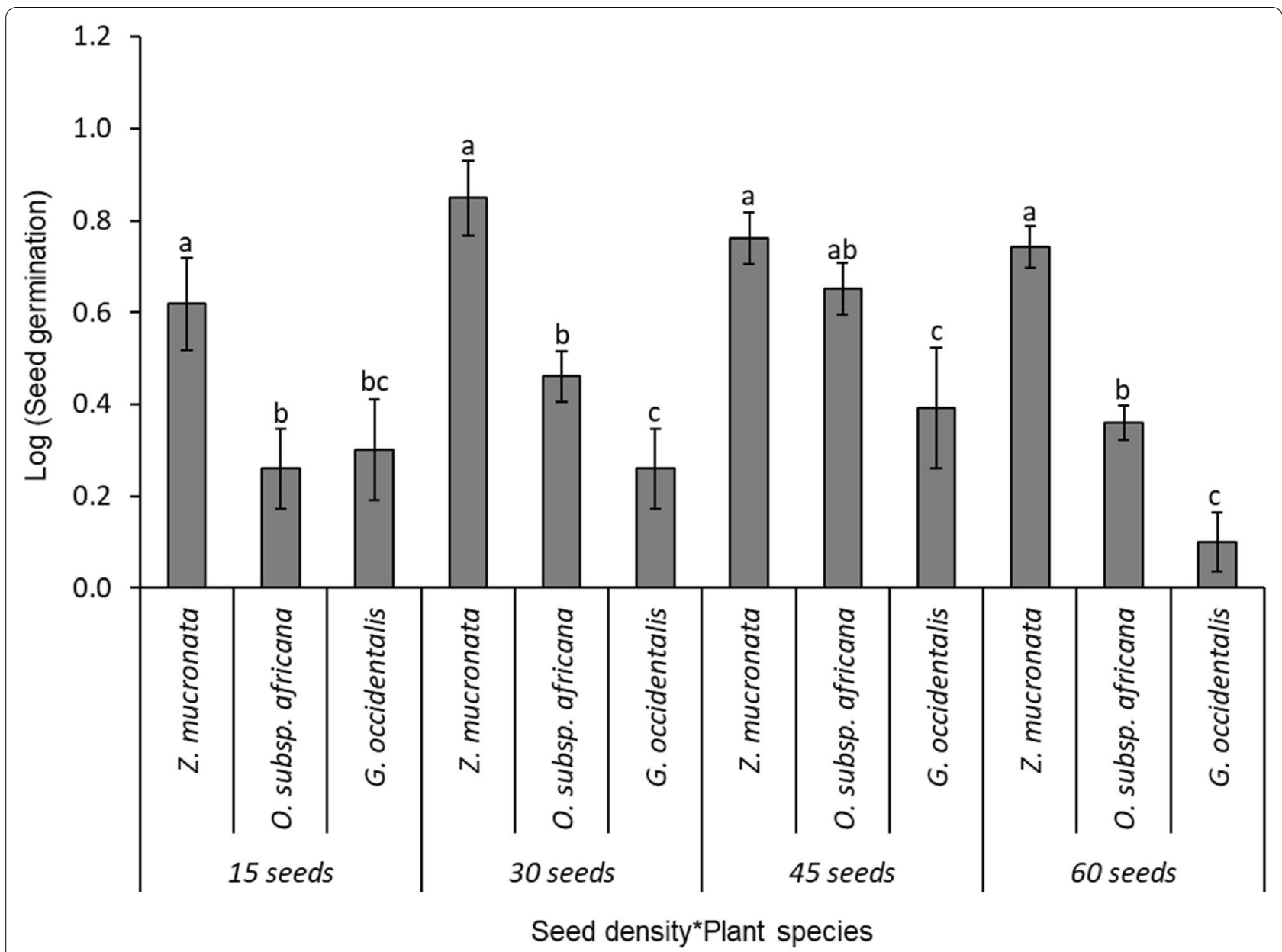

Fig. 5 Mean seed germination for different plant species in competition level 2 between three tree/shrub species: Z. mucronate, O. subsp. africana and $G$. accidentalis. The error bars represent the standard error of sample mean, and different letters above standard error bar denote significant differences between seed density levels

$(12.5 \pm 2.3 \%)$, and O. subsp. africana $(5.8 \pm 2.1 \%)$; were highly significant $\left(\mathrm{F}_{(3,80)}=39.2 ; \mathrm{p}<0.001\right.$; Fig. 6), and there were significant differences in the seed germination across the different seed density levels $\left(F_{(3,80)}=7.3 ; p=0.0002\right)$. The Tukey HSD test showed that, while the germination rate for Z. mucronata was significantly high, S. lancea and G. occidentalis had equivalent germination rates, but they were significantly greater than those for O. subsp. africana. There were significant interactions between the tree/shrub species and the density levels $\left(F_{(9,80)}=1.9 ; p=0.051\right.$; Fig. 6), with $Z$. mucronata having a significantly higher seed germination rate in seed densities of $40(76.7 \pm 11.2 \%)$, $60(64.4 \pm 13.4 \%)$, and $80(45.0 \pm 9.1 \%)$ than the other shrubs, while $Z$. mucronata and S. lancea have greater seed germination percentages than the other two species at seed density of 20 (53.3 $\pm 11.2 \%$; $33.3 \pm 4.2 \%$; Fig. 6)

(iv) Level 4 competition: five tree/shrub species ( $Z$. mucronata, G. occidentalis, S. lancea, E. rigida, and O. subsp. africana)

The comparisons of the bird-ingested seed germination rates among five competing tree/shrub species $-Z$. mucronata (mean $\pm \mathrm{SE}: 44.7 \pm 8.1 \% ; \mathrm{N}=250$ ), O. subsp. africana (21.1 $\pm 9.6 \%)$, S. lancea $(19.4 \pm 5.6 \%)$, G. occidentalis $(11.4 \pm 3.7 \%)$, and E. rigida $(0.0 \pm 0.0 \%)$; Fig. $7-$ were highly significant $\left(\mathrm{F}_{(4,100)}=35.8 ; \mathrm{p}<0.001\right.$; Fig. 7$)$. The Tukey HSD test showed that, while $Z$. mucronata was significantly greater than other species, those for the next three tree/shrub species were not significantly different from one another but were significantly greater 


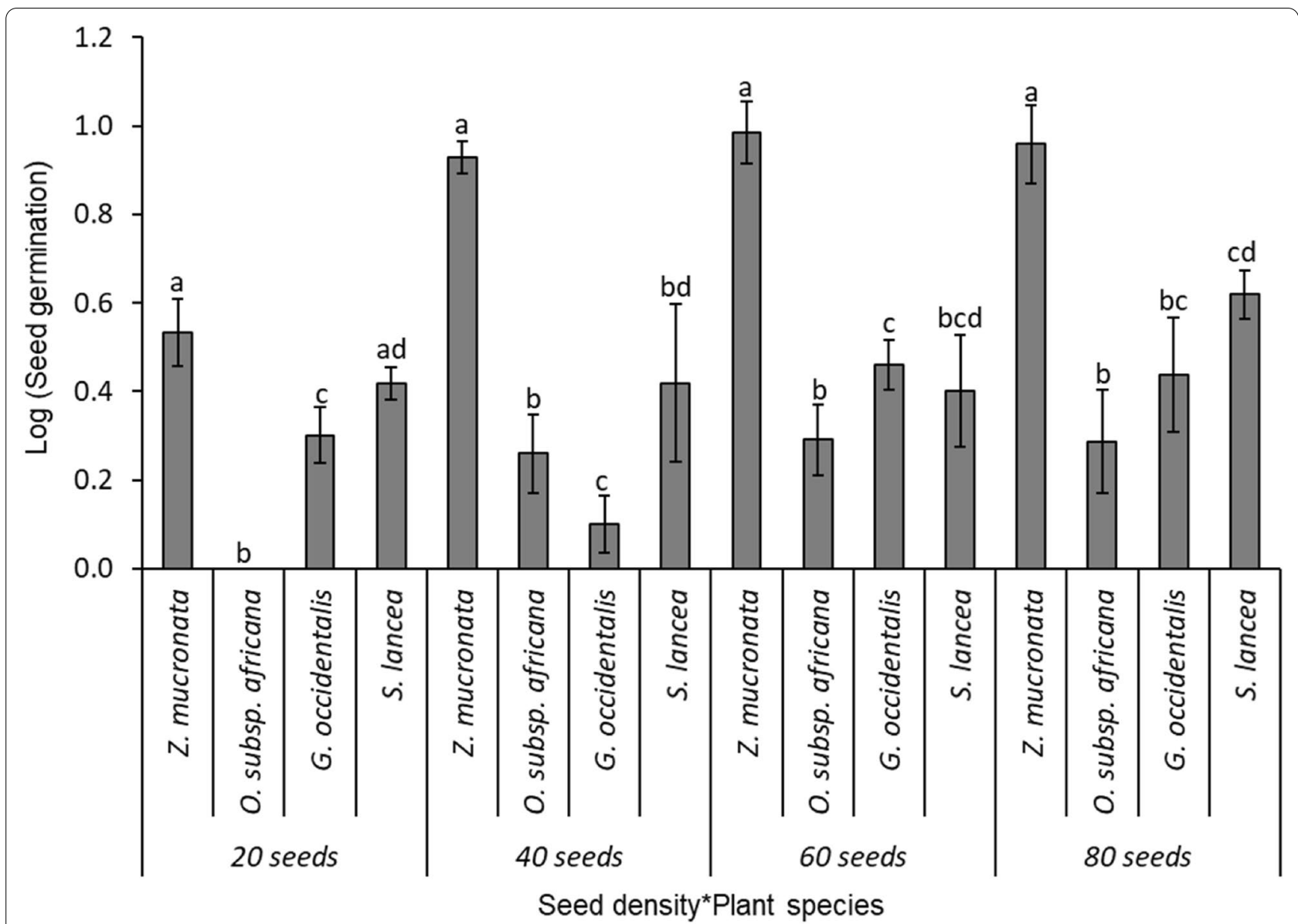

Fig. 6 Mean seed germination for different plant species in competition level 3 between four tree/shrub species: Z. mucronate, O. subsp. africana, G. accidentalis and S. lancea. The error bars represent the standard error of sample mean, and different letters above standard error bar denote significant differences between seed density levels

than for E. rigida. There were no significant differences in the seed germination at different seed density levels $\left(\mathrm{F}_{(3,100)}=0.7 ; \mathrm{p}=0.568\right.$; Fig. 7). There was no significant interaction between the seed density levels and the tree/ shrub species $\left(\mathrm{F}_{(12,100)}=1.6 ; \mathrm{p}=0.114\right)$, while $Z$. mucronata, had the highest seed germination rate when the total seed density was $75(55.6 \pm 14.9 \%)$, and partly when the density was 50 (53.3 $\pm 4.2 \%$; Fig. 7$)$.

\section{Germination pattern of Z. mucronata and O. subsp. africana across the seed density levels}

Overall, Z. mucronata was the strongest competitor against the other tree/shrub species, with significantly higher seed germination rates recorded across the different levels of seed density $\left(\mathrm{H}_{(11,96)}=30.5 ; P=0.0013\right.$; Fig. 8A). The multiple comparison test showed that $Z$. mucronata's seed germination was significantly
$(P=0.0499)$ highest at the seed densities of 30 (mean rank: 67.8), 60 (61.8), 75 (63.8), and 80 (70.5), and these levels did not differ significantly $(P>0.05)$ among one other (Fig. 8A).

There was a significant positive correlation between the germination of the bird-ingested seeds of $Z$. mucronata and the seed density levels per tray (Spearman rank order correlation: $\mathrm{r}=0.268 ; \mathrm{N}=96 ; P=0.008$ ).

Additionally, O. subsp. africana also displayed the significant increase in the germination rate as the seed density per tray increase $\left(\mathrm{H}_{(11,96)}=26.2 ; P=0.0061\right.$; Fig. 8B). The multiple comparisons tests showed that these differences were recorded only at the seed density level of 45 with mean rank 81.8 against the seed density level of 20 with mean rank $24.7(P=0027)$. Similarly, the seed germination rate showed a significant positive correlation to the seed density (Spearman rank order correlation: $\mathrm{r}=0.300 ; \mathrm{N}=96 ; P=0.003)$. 


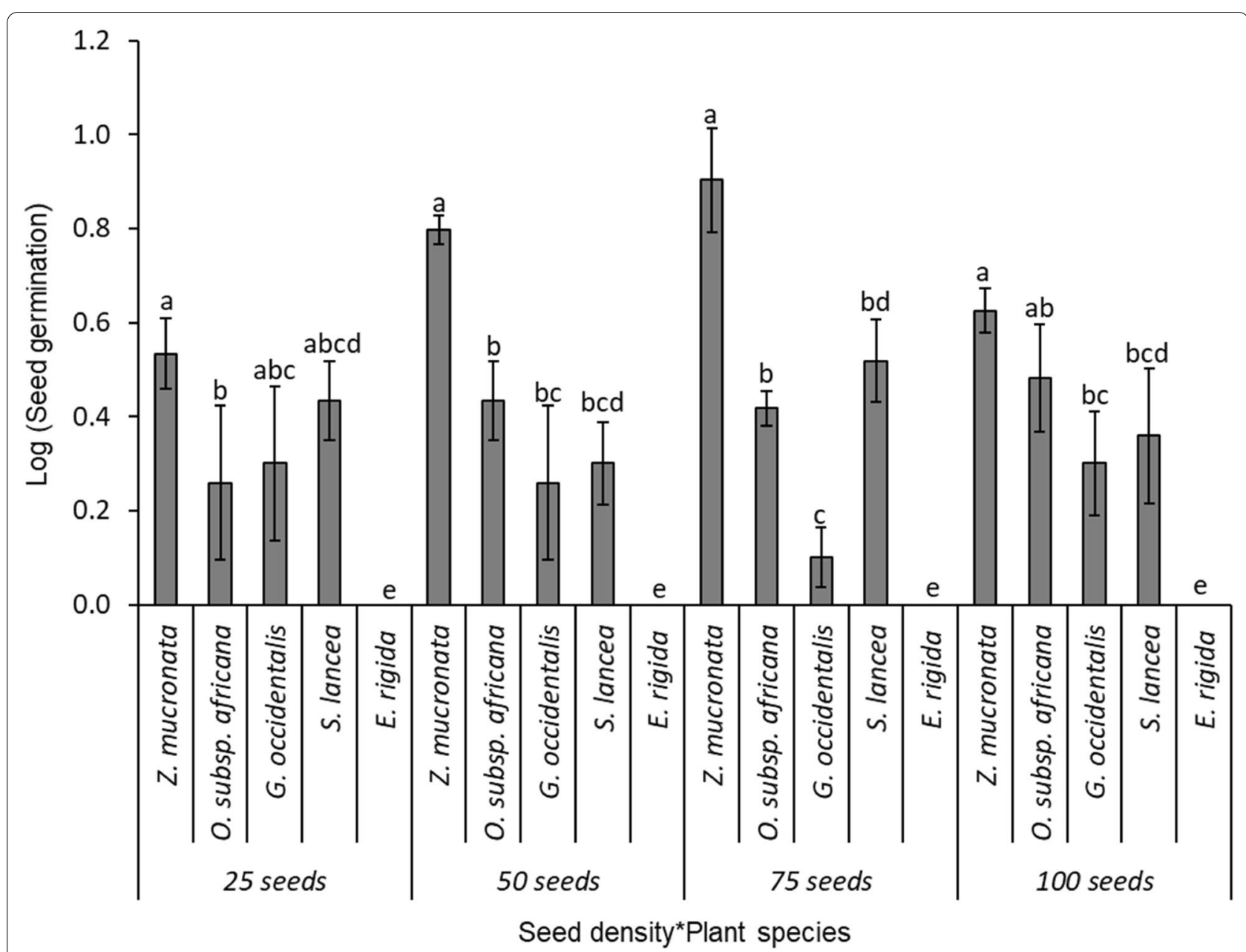

Fig. 7 Mean seed germination for different plant species in competition level 4 between five tree/shrub species: Z. mucronate, O. subsp. africana, G. accidentalis, S. lancea and E. rigida. The error bars represent the standard error of sample mean, and different letters above standard error bar denote significant differences between seed density levels
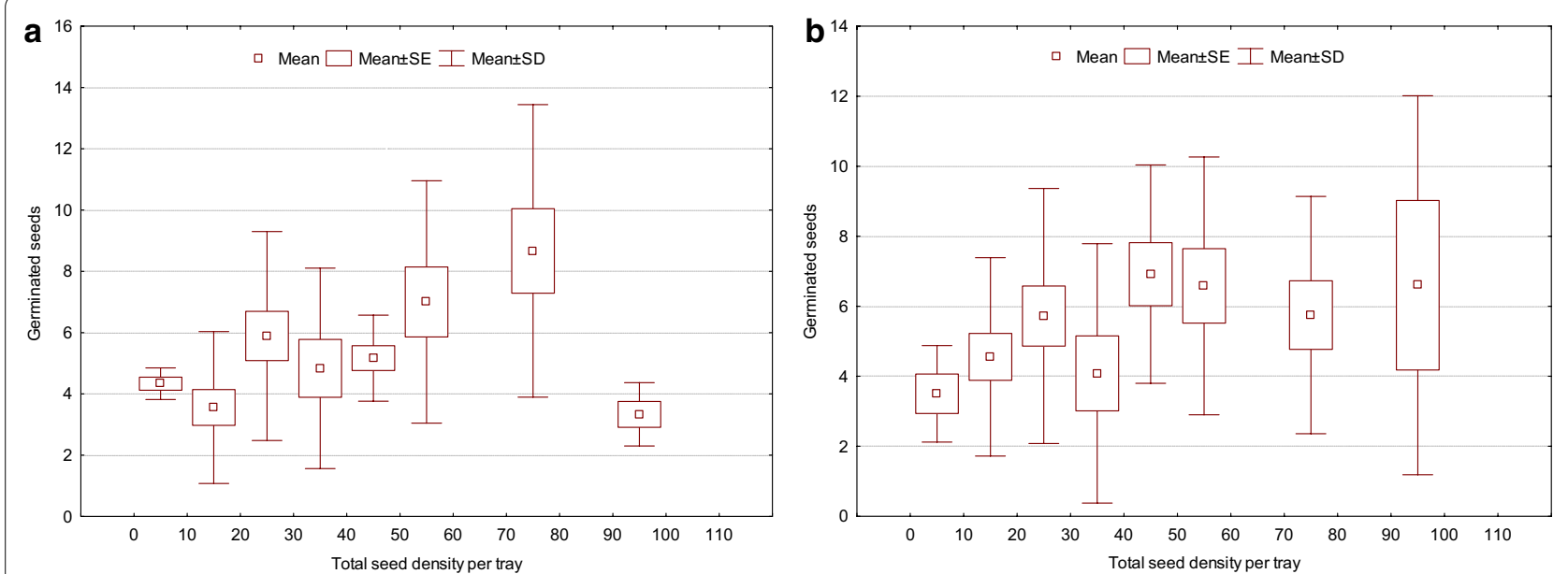

Fig. 8 Overall variation in germination of bird-ingested seeds for Z. mucronata $(\mathbf{A})$ and O. subsp. africana $(\mathbf{B})$ across seed density levels (i.e., 10-100 seeds per tray) with different competing species 


\section{Discussion}

\section{Germination trials: bird-ingested vs depulped seeds}

We tested the hypothesis that the passage of seeds through birds' gut improves germination and foundcontrary to the hypothe-that bird-ingested seed germination improvement was not observed in four of the five tree/shrub species. Only S. lancea seeds had their germination improved by passage through birds' gut, probably due to scarification of the seeds' coat/endocarp in the avian digestive tract (Mokotjomela et al. 2015; Samuels and Levey 2005; Traveset et al. 2001), suggesting that this woody species benefits from a higher effectiveness of seed dispersal from birds than the others. In addition, the ingestion of $S$. lancea seeds by birds may release seed dormancy through the scarification associated with digestive processes (Mokotjomela et al. 2015; Traveset et al. 2001) and this also prevents the latent problems of either endogenous predation or disease that are reported in $60 \%$ of harvested seeds (Weiersbye and Witkowski 2002), thereby suggesting that S. lancea has a soft seed cover with limited resistance to microbial attack.

On the other hand, the unchanged germination rates of the bird-ingested seeds of O. subsp. africana, E. rigida, and $Z$. mucronata are likely the result of the high resistance of their seed cover to treatment in the gut, as reported by Mokotjomela et al. (2015) for the seeds of Acacia cyclops, in combination with the limited retention times when the seeds are ingested by large vectors (Tsoar et al. 2011; Schurr et al. 2009). The observed low germination of $O$. subsp. africana could be attributed to indehiscent, stony, and hard endocarp (Cuneo et al. 2010), which prevent germination by stopping moisture and oxygen from reaching the seed (Negash 2010; Bekele 2000). Also, O. subsp. africana seeds have a high seed dormancy that may persist for up to 35 months (Bekele 2000), which indicates uncertainty about the seed's viability. The poor germination observed in E. rigida may be associated with an inherently low seed viability ( 26\%; Wilman et al. 2014), and a low tolerance to moisture and humidity (Louw 2012), whereas the study site has a humid microclimate due to the presence of a dam and wetland. This finding suggests that E. rigida is adapted to arid environments, as indicated by Wilman et al. (2014), and that it requires relatively low and intermittent moisture for successful seed germination (Wilman et al. 2014). We suggest that the unchanged but high seed germination in $Z$. mucronata is due to it having a large seed size that, reportedly (Mandal et al. 2008), also enhanced germination in the seeds of Hyptis suaveolens. This explanation can also hold for Z. mucronata, since we consistently found a significant positive correlation between seed size and germination rates. In addition, $Z$. mucronata has a high seed viability of up to $100 \%$
(Weiersbye and Witkowski 2002) and a high physiological plasticity in a broad variety of environmental conditions (Refka et al. 2013; Zietsman and Botha 1987). An unchanged germination of bird-ingested seeds has been previously reported in South Africa (Mokotjomela et al. 2015; Chama et al. 2013; Mokotjomela et al. 2021; Jordano et al. 2016), which highlights, in this context, the role of birds in transporting seeds to new microsites. However, we argue that these tree/shrub species could have evolved resistant seed covers in order to endure environmental uncertainties such as rodents' seed predation, diseases, and droughts (Pearson et al. 2014; Dardick and Callahan 2014). Thus, further investigation that is beyond the scope of this study might yield better insight into the roles of the reported characteristics in the life of seeds in the local context.

Only S. lancea and Z. mucronata have their seed germination speed significantly accelerated, suggesting that those tree/shrub species benefited from scarification of the seeds' coat in the avian digestive tract (Mokotjomela et al. 2016; Traveset et al. 2001), of which likely released seed dormancy (Vellend 2010). Seed abrasions and scarification by birds increase seed coat permeability and thus, quick imbibition (Mokotjomela et al. 2016; Figueroa and Castro 2002). Also, the medium-size bird Olive thrush (Turdus olivaceus) was most dominant bird in the study site, and Godínez-Alvarez et al. (2020) showed that the medium birds have longer gut tract retention time for seeds of which is critical for seed treatment. Consistently, the blackbirds (Turdus merula) are known to improve seed germination for woody plant species elsewhere (Barnea et al. 1991). Our results were similar with the findings of Mokotjomela et al. (2016), who reported that the bird's gut treatment accelerated seed germination speed of the two cacti species in South Africa. Accelerated seed germination provides a competitive advantage of low seedlings' competition for resources and thus promote plant species recruitment.

\section{Interspecific competition for seed germination: seed density and species diversity}

Germination is a key process for maintaining plants' genetic material in order to sustain species' population after their seeds are dispersed to new microsites (Carlo and Tewksbury 2013; Hulme 1998). When seeds of different plant species interact, their ability to affect and respond to competition determines the contribution of seed germination to individual plant species' population (Bergelson and Perry 1989; Lortie and Turkington 2002; Orrock and Christopher 2010; Tielborger and Prasse 2009; Schupp 1993). Part of this study investigated how bird-dispersed seeds handle competition 
mediated through seed density and species diversity in the microsite.

Our finding that $Z$. mucronata's seed germination performance increased with seed density and species diversity may be due to its high behavioural plasticity (Refka et al. 2013; Zietsman and Botha 1987), an attribute that has possibly allowed $Z$. mucronata to endure emerging physiological conditions when competing for survival with other species. Similar results were reported by Orrock and Christopher (2010), who observed an accelerated germination response of Phytolacca americana when seed density was increased. Indeed, dispersed seeds may have to overcome a variety of environmental pressures against germination to attain their subsequent plant recruitment (Orrock and Christopher 2010; Wang and Smith 2002). If the experimental germination trays represented a microsite that was conducive to dispersed seeds, as proposed by Howe (1986), then - in line with the enemy release hypothesis (i.e., for invader species), which postulates that new environments have either few or less competitive neighbours (Le Roux et al. 2020), we argue that this could have enhanced $Z$. mucronata's seed germination. Our study also highlights that the number of seeds (i.e., the amount of dispersal effectiveness, sensu, Schupp et al. 2010) in the microsite is important for the effective initiation of the recruitment process for each plant (Hulme 1998; Howe 1986) because, at a seed density of between 60 and 100, there was no significant increase in germination. Seeds' endocarp has some hormones that play a major role in maintaining seed dormancy and in protecting the embryo against pathogens by producing phenolic compounds (i.e., tannins) (Raviv et al. 2017). If the seeds of different species can sense each other prior to their emergence (Ward 2016; Tielborger and Prasse 2009), it is possible that the endocarp of the germinated seeds of $Z$. muconata released chemicals and/or hormones that eventually suppressed the germination of neighbouring seeds, while it enjoyed all the germination resources available at the microsite. The impact of the suggested chemical effect could be amplified by the large seed size of $Z$. mucronata.

The fact that O. subsp. africana displayed an increasing seed germination in the level two competition (i.e., a total seed density of 15-45; the competing species were $Z$. mucronata and G. occidentalis), suggests that there could have been a physiological enhancement from the seeds of other species, since Negash (2010) and Cuneo et al. (2010) found that the hard seed endocarp of $O$. subsp. africana thwarts the germination process. It has been consistently shown that dispersed seeds adjust their dormancy status in relation to the new conditions in the microsite, while also targeting the optimal conditions for germination (Footitt et al. 2018), and that they can sense the presence of seeds of other species (Tielborger and Prasse 2009). Because the passage of seeds through birds' gut did not also improve the germination of O. subsp. africana, we argue that the disintegration of the endorcarps of the substantially germinated seeds of $Z$. mucronata might have resulted in new physiological effects that favoured seed germination in O. subsp. africana.

The poor seed germination of G. occidantalis and the failed germination of $E$. rigida (i.e., in competition Level 3: species: Z. mucronata, O. subsp. africana, G. occidantalis, and S. lancea; and Level 4: species: Z. mucronata, O. subsp. africana, G. occidantalis, S. lancea, and E. rigida) could be partly attributed to the adaptive mechanisms related to a need for the persistence of dispersed seeds through protection against microbes and physiological barriers to their germination (Dalling et al. 2011). Orthodox seeds tend to dry up to preserve their viability (Hilhost and Toorop 1997), and this requires some treatment to break their dormancy (Qasem 2019; Rowarth et al. 2007). Bewley and Nonogaki (2017) distinguished between the sequence of the different physiological stages of the germination process, and they contended that, during the imbibition phase of germination in dry seeds (i.e., orthodox), germination may be prolonged if all the essential protein are not available to reinitiate the metabolism in the dormant seeds. Moreover, it has been shown that dispersed seeds undergo a transition of dormancy that is mediated by the maternal plant to an independent seed-mediated dormancy, which is also aligned with the new conditions at the location where the seed is deposited (Finch-Savage and Footitt 2017; Footitt et al. 2013). Thus, it is possible that the seed germination of the species in our study that were dispersed between March and July was retarded by the dormancy transition mentioned above. The emergence of the seed in some species may not be necessarily because of competition, but also because of the factors were not controllable such as fruit maturing time and their consumption by birds although all seeds were sown at age before dormancy was changed.

Recalcitrant seeds must be sown immediately after harvesting or being dispersed (Barbedo et al. 2013), unlike orthodox seeds (Z. mucronata, G. occidentalis, O. subsp. africana, and E. rigida). We suggest that the poor seed germination performance in $S$. lancea, as a recalcitrant seeder, could be partly due to the loss of its viability through dehydration during storage, which corroborates a report that $S$. lancea seeds are sensitive to moisture and thermal stress (Nichols 2005). Furthermore, this observation may be explained by the small seed size of S. lancea, which reportedly promotes persistence in the soil better than is the case with large seeds (Mole et al. 2000; Funes et al. 1999). 


\section{Concluding remarks}

Our germination trials with the bird-ingested seeds extracted from faecal samples showed that the foraging birds provide seed dispersal service in two different ways relating to quality and quantity of dispersal effectiveness (Kleyheeg et al. 2018; Mokotjomela et al. 2016; Schupp et al. 2010). These are the partly improved seed germination success and its rate after passage through the bird gut; and solely, the transport of the seeds to new microsites. Although there was limited improvement seed germination success restricted to $S$. lancea, we noted that seed germination speed increased in S. lancea and $Z$. mucronata of which may provide competitive advantage for seedlings.

Foraging birds disperse the ingested seeds away from their maternal plant to the new microsite where there is less intra- and inter-species competition for resources that might be limited where siblings' and congeners' populations are large (Howe 1986). However, the results of this study suggest that beyond the seed dispersal and deposition, interspecific seed competition for germination resources still occur. The reported competition has implications for dispersal effectiveness since not all dispersed seeds germinated. We speculated that a prolific performance of $Z$. mucronata and O. subsp. africana is partly due to the reported behavioural plasticity in combination with seeds' physiological defence to the competitors or change in the critical environmental conditions such as moisture in germination trays. As we cannot conclude that seed emergence of other species was due to inability to compete, further, studies on the physiological interactions of seeds underground are needed for elucidating on the germination behaviour of individual focal tree/shrub species. Finally, the high seed germination of the large seeded Z. mucronata in this study, explains its predominance in the reported bush encroachment in the study site (Vukeya et al. 2020; Department of Environmental Affairs, 2019; Zietsman et al. 1989), thus we recommend adaptive conservation management plan should include monitoring and prioritised population control for this species to maintain ecological balance with other species.

\section{Acknowledgements}

We thank Free State National Botanical Garden (FSNBG), Nursey department for providing the Green House Facility for germination trails, and the staff who assisted in setting up the experiments.

\section{Authors' contributions}

LV and TMM conceived the study, set up the experiments in FSNBG, LV collected data, TMM and LV analysed the data. LV, TMM, NM \& OK wrote the manuscript. All authors have read and approved the final manuscript.

\section{Funding}

Funding support for this study was provided by the South African National Biodiversity Institute (SANBI), Centre for Invasion Biology (CIB) and Central University of Technology (Free State's Research Grants and Scholarship).
Availability of data and materials

Not applicable.

\section{Declarations}

Ethics approval and consent to participate

Not applicable.

\section{Consent for publication \\ Not applicable.}

\section{Competing interests}

Authors declare no conflict of interest.

\section{Author details}

${ }^{1}$ Centre for Invasion Biology, South Africa National Biodiversity Institute, Free State National Botanical Garden, Free State, Rayton, Dan Pienaar, Danhof, P.O Box 29036, Bloemfontein 9310, South Africa. ${ }^{2}$ South Africa National Biodiversity Institute, Free State National Botanical Garden, Free State, Rayton, Dan Pienaar, Danhof, P.O Box 29036, Bloemfontein 9310, South Africa. ${ }^{3}$ Faculty of Health and Environmental Science, Central University of Technology, Private Bag X20539, Bloemfontein 9300, South Africa. ${ }^{4}$ School of Life Sciences, University of KwaZulu-Natal, P/Bag X01, Scottsville, Pietermaritzburg 3209, South Africa.

Received: 4 December 2020 Accepted: 17 May 2021

Published online: 10 June 2021

\section{References}

Alves-Costa CP, Eterovickb PC (2007) Seed dispersal services by coatis (Nasuanasua, Procyonidae) and their redundancy with other frugivores in southeastern Brazil. Acta Oecologica 32:77-92

Angaine PM, Ndungú SM, Onyango AA, Owino JO (2020) Effect of desiccation and storage environment on longevity of Ehretia Cymosa thonn. Seeds. https://doi.org/10.21203/rs.3.rs-43618/v1

Aschehoug ET, Brooker R, Atwater DZ, Maron JL, Callaway RM (2016) The mechanisms and consequences of interspecific competition among plants. Annu Rev Ecol Evol Syst 47:263-281

Aukema JE, Martinez Del Rio C (2002) Where does a fruit-eating bird deposit mistletoe seeds? Seed deposition patterns and an experiment. Ecology 83(12):3489-3496

Baños-Villalba A, Blanco G, Díaz-Luque JA, Dénes FV, Hiraldo F, Tella JL (2017) Seed dispersal by macaws shapes the landscape of an Amazonian ecosystem. Sci Report. https://doi.org/10.1038/s41598-017-07697-5

Barbedo CJ, Centeno DC, Ribeiro D (2013) Do recalcitrant seeds really exist? Hoehnea 40(4):583-593

Barnea A, Yom-Tov Y, Friedman J (1991) Does ingestion by birds affects seed germination. Funct Ecol 5:394-402

Bekele T (2000) Plant population dynamics of Dodonaea angustifolia and Olea europaea ssp. cuspidata in Dry Afromontane Forests of Ethiopia. Acta Universitatts Upsaliensis 559:1-47

Bergelson J, Perry R (1989) Interspecific competition between seeds: relative planting date and density affect seedling emergence. Ecology 70(6):1639-1644

Bewley JD, Nonogaki H (2017) Seed maturation and germination. In: Nonogaki $H$ (ed) Module in life science. Elsevier, Amsterdam

Cardazzo CV (2002) Effect of seed mass on germination and growth in three dominant species in southern Brazilian costal dunes. Braz J Biol 62(3):427-435

Carlo TA, Tewsbury JJ (2013) Directness and tempo of avian seed dispersal increases emergence of wild chiltepins in desert grasslands. J Ecol 102(1):248-255

Castilla AR, Pope NS, Oconnell M, Rodriguez MF, Treviño L, Santos A, Jha S (2017) Adding landscape genetics and individual traits to the ecosystem function paradigm reveals the importance of species functional breadth. PNAS 114(48):12761-12766 
Chama L, Berens DG, Downs CT, Farwig N (2013) Do frugivores enhance germination success of plant species? An experimental approach. S Afr J Bot 88:23-27

Chaplin PJ (1979) Orange Free State Botanic Gardens. In: Africa, T.N.B.G.O.S. (Ed.). Bloemfotein Volkskas (Ltd).

Cuneo P, Offord CA, Leishman MR (2010) Seed ecology of the invasive woody plant African Olive (Olea europaea subsp. cuspidata): implications for management and restoration. Aust J Bot 58:342-348

Dalling JW, Davis AS, Schutte BJ, Arnold AE (2011) Seed survival in soil: interacting effects of predation, dormancy and the soil microbial community. J Ecol 99:89-95

Dardick C, Callahan AM (2014) Evolution of the fruit endocarp: molecular mechanisms underlying adaptations in seed protection and dispersal strategies. Front Plant Sci 5:284

JC Delouche (1961) Application of the tetrazolium test to cotton and soybeans Mississippi State University (Agricultural Experiment Station) Seed Technology Laboratory

Department of Environmental Affairs (DEA). 2019. Towards a policy on indigenous bush encroachment in South Africa. Pretoria, South Africa.

Dlamini P, Zachariades C, Downs CT (2018) The effect of frugivorous birds on seed dispersal and germination of the invasive Brazilian pepper tree (Schinus terebinthifolius) and Indian laurel (Litsea glutinosa). S Afr J Bot 114:61-68

Egerer MH, Fricke EC, Rogers HS (2018) Seed dispersal as an ecosystem service: frugivore loss leads to decline of a socially valued plant Capsicum Frutescens. Ecol Appl 28(3):655-667

Fabbri A, Bartolini G, Lambardi M, Kailis S (2004) Olive propagation manual. Landlinks Press, Collingwood

Figueroa JA, Castro SA (2002) Effects of bird ingestion on seed germination of four woody species of the temperate rainforest of Chilo'e island. Chile Plant Ecol 160:17-23

Finch-Savage WE, Footitt S (2016) Seed dormancy cycling and the regulation of dormancy mechanisms to time germination in variable field environments. J Exp Bot 68(4):843-856

Footitt S, Huang Z, Clay HA, Mead A, Finch-Savage WE (2013) Temperature, light and nitrate sensing coordinate Arabidopsis seed dormancy cycling, resulting in winter and summer annual phenotypes. Plant J 47:1003-1015

Footitt S, Awan S, Finch-Savage WE (2018) An improved method for the rapidisolation of RNA for Arabidopsis and seeds of other species high in polyphenols and polysaccaharides. Seed Sci Res 28(4):360-364

França-Neto JB, Krzyzanowski FC (2019) Tetrazolium: an important test for physiological seed quality evaluation. J Seed Sci 41(3):359-366

Fricke EC, Simon MJ, Reagan KM, Levey DJ, Riffell JA, Carlo TA, Tewksbury JJ (2013) When condition trumps location: seed consumption by fruiteating birds removes pathogens and predator attractants. Ecol Lett 16:1031-1036

Funes G, Basconcelo S, Diaz S, Cabido M (1999) Seed size and shape are good predictors of seed persistence in soil in temperate mountain grasslands of Argentina. Seed Sci Res 9:341-345

Gloria M, Pyšek P, Osborne B (2018) Timing is everything: does early and late germination favor invasions by herbaceous alien plants? J Plant Ecol 11(1):4-16

Godínez-Alvarez H, Ríos-Casanova L, Peco B (2020) Are large frugivorous birds better seed dispersers than medium- and small-sized ones? Effect of body mass on seed dispersal effectiveness. Ecol Evol 00:1-8. https://doi. org/10.1002/ece3.6285

Goets SA, Kraaij T, Little KM (2018) Seeds bank and growth comparisons of native (Virgilia divaricate) and invasive alien (Acacia mearnsii and A.melanoxylon) plants: implications for conservation. Peer J 6:e5466

Guido A, Hoss D, Pillar VD (2017) Exploring seed to seed effect for understanding invasive species success. Perspect Ecol Conser 15:234-238

Haddad CR, Jager LJC, Foord SH (2019) Habitats and cardinal directions are key variables structuring spider leaf litter assemblages under Searsia lancea. Pedobiologia 73:10-19

Hassen A, Rethman NFG, Van Niekerk WA (2005) Research note: Effect of different seed treatment options on dormancy breaking, germination and emergence of Ziziphus mucronata (buffalo thorn) seed. Trop Grassl 39:124-128
Heleno SA, Barros L, Sousa ML, Martins A, Santos-Buelga C, Ferreira ICFR (2011) Targeted metabolites analysis in wild Boletus species. LWT Food Sci Technol 44:1343-1348

Heuzé V, Tran G, Delagarde R, Bastianelli D, Lebas F (2015) False brandy bush (Grewia bicolor). Feedipedia, a programme by INRAE, CIRAD, AFZ and FAO. https://www.feedipedia.org/node/148 Last updated 3 July 2015, $11: 20$

Higgins SI, Nathan R, Cain ML (2003) Are long-distance dispersal events in plants usually caused by nonstandard means of dispersal? Ecology 84:1945-1956

Hilhorst HWM, Toorop PE (1997) Review on dormancy, germinability and germination in crop and weed seeds. Adv Agron 61:112-165

Howe HF (1986) Consequences of seed dispersal by birds: a case study from Central America. J Bombay Nat Hist Soc 83:19-42

Howe HF (2016) Making dispersal syndromes and networks useful in tropical conservation and restoration. Glob Ecol Conserv 6:152-178

Hulme PE (1998) Post-dispersal seed predation and seed bank persistence. Seed Sci Res 8:513-519

Johnson MTJ, Dinnage R, Zhou AY, Hunter MD (2008) Environmental variation has stronger effects than genotype on competation among plant species. J Ecol 96(5):947-955

Jones LR, Duke-Sylvester SM, Leberg PL, Fc DM (2017) Closing the gaps for animal seed dispersal: separating the effects of habitat loss on dispersal distances and seed aggregation. Ecol Evol 7:5410-5425

Jordano P (2000) Fruits and frugivory. In: Fenner M (ed) Seeds: the ecology of regeneration in natural plant communities. CABI Publishers, Wallingford, pp 125-166

Jordano P (2016) Sampling networks of ecological interactions. Funct Ecol 30:1883-1893. https://doi.org/10.1111/1365-2435.12763

Kahmen S, Poschlod P (2008) Does germination success differ with respect to seed mass and germination season? Experimental testing of plant functional trail responses to grassland management. Ann Bot 101:541-548

Kays R, Tilak S, Kranstauber B, Jansen PA, Carbone C, Rowcliffe M, He Z (2011) Camera traps as sensor networks for monitoring animal communities. Int J Res Rev Wireless Sens Netw 1(2):19-29

Kleyheeg E, Claessens M, Soons MB (2018) Interactions between seed traits and digestive processes determine the germinability of bird-dispersed seeds. PLoS ONE. https://doi.org/10.1371/journal.pone.0195026

Kolodziejek J (2017) Effect of seed position and soil nutrients on seed mass, germination and seedling growth in Peucedanum oreoselinum (Apiaceae). Sci Rep 7:1959

Körner C, Stöcklin J, Reuther-Thiébaud L, Pelaez-Riedl S (2007) Small differences in arrival time influence composition and productivity of plant communities. New Phytol 177:698-705

Le Roux JJ et al (2020) Biotic interactions as mediators of biological invasions: insights from South Africa. In: van Wilgen B, Measey J, Richardson D, Wilson J, Zengeya T (eds) Biological invasions in South Africa Invading nature - Springer series in invasion ecology, vol 14. Springer, Cham. https://doi.org/10.1007/978-3-030-32394-3_14

Lortie CJ, Turkington R (2002) The effect of initial seed density on the structure of a desert annual plant community. J Ecol 90:435-445

Louw M (2012) Propagation and stree phsiology of selected Subtrpical Thicket species: towards increasing biodiversity at rehabilitation sites. Nelson Mandela Metropolitan University

Maguire JD (1962) Speed of germination - aid in selection and evaluation for seedling emergence and vigor. Crop Sci 2:176-177

Mandal SM, Chakraborty D, Gupta K (2008) Seed size variation: influence on germination and subsequent seedling performance in Hyptis souaveolens (Lamiaceae). Res J Seed Sci 1(1):26-33

T Masilo (1999) The development of ISO 14001-based environmental management in the Free State National Botanical Garden University Free State Environmetal Management

Miransari M, Smith DL (2014) Plant hormones and seed germination. Environ Exp Bot 99:110-121

Mokotjomela TM, Musil CF, Esler KJ (2009) Is Solanum mauritianum a preferential food resource for native frugivores in the Cape Floristic Region? S Afr J Bot 75(2):436

Mokotjomela TM, Musil CF, Esler KJ (2013) Frugivorous birds visit fruits of emerging alien shrub species more frequently than those of native shrubs species in the South African Mediterranean climate region. S Afr J Bot 86:73-78 
Mokotjomela TM, Hoffmann JH, Downs CT (2015) The potential for birds to disperse the seeds of Acacia cyclops, an invasive alien plant in South Africa. Ibis 157(3):449-458

Mokotjomela TM, Downs CT, Esler K, Knight J (2016) Seed dispersal effectiveness: A comparison of four bird species feeding on seeds of invasive Acacia cyclops in South Africa. S Afr J Bot 105:259-263

Mokotjomela TM, Thabethe V, Downs C (2021) Comparing germination metrics of Opuntia ficus-indica and O. robusta between two sets of bird species (Pied Crows and smaller species). Acta Oecol 110:103676

Moles AT, Westoby M (2004) Seedling survival and seed size: a synthesis of the literature. J Ecol 92:372-383

Moles AT, Hodson DW, Webb CJ (2000) Do seed size and shape predict persistence in soil in New Zealand? Oikos 89:541-545

Moles AT, Warton DI, Westoby M (2003) Seed size and survival in the soil in arid Australia. Austral Ecol 28:575-585

Mucina MC, Rutherford LM eds. (2006) Vegetation of South africa, Lesotho and Swaziland. Pretoria: Strelitzia Vol 19, SANBI

Muller-Landau HC, Hardesty BD (2005) Seed dispersal od woody plants in tropical forests: concepts, examples, and future directions. In: Burslem D, Pinard M, Hartley S (eds) Biotic in the Maintenance of Species Diversity. Cambridge Unversity Press, Cambridge, pp 267-309

Nathan R, Schurr FM, Spiegel O, Steinitz O, Trakhtenbrot A, Tsoar A (2008) Mechanisms of long-distance seed dispersal. Trends Ecol Evol 23:638-647

Neethling JA, Haddad CR (2013) Arboreal spider assemblages associated with four tree species in the Grassland Biome of central South Africa (Arachnida: Araneae). Trans R Soc South Africa 68(2):123-131

Negash L (2010) A Selection of Ethiopia's Indigenous Trees: Biology Uses and Propagation Techniques. Addis Ababa University Press, Addis Ababa

Nichols G (2005) Growing rare plants: a practical handbook on propagating the threatened plants of southern Africa. Southern African Botanical Diversity Network Report No. 36. SABONET, Pretoria.

Orrock JL, Christopher CC (2010) Density of intraspecific competitors determines the occurrence and benefits of accelerated germination. Am J Bot 97(4):694-699

Patil VN, Dadlani MV (2009) Tetrazolium test for seed viability and vigour. In: McDonalds MB, Kwon FY (eds) Flower seeds: biology and technology handbook. CABI, Oxfordshire

Pearson DE, Hierro JL, Chuiuffo M, Villarreal D (2014) Rodent seed predation as a biotic filter influencing exotic plant abundance and distribution. Biol Invasions 16:1185-1196

Pidilla DP, GonzaLez-Castro A, Nogales M (2012) Significance and extent of secondary seed dispersal by predatory birds on oceanic islands the case of the Canary archipelago. J Ecol 100:416-427

Qasem JR (2019) Weed Seed Dormancy: the Ecophysiology and Survival Strategies. Seed Dormancy Germination. https://doi.org/10.5772/intec hopen.88015

Ranal MA, Santana DG (2006) How and why to measure the germination process? Revista Brasil Bot 29(1):1-11

Raviv B, Aghajanyan L, Granot G, Makover V, Frenkel O, Gutterman Y, Grafi G (2017) The dead seed coat functions as a long-term storage for active hydrolytic enzymes. PLOS ONE 12(7):e0181102

Refka Z, Mustapha K, Ali AND, F. (2013) Seed germination characteristics of Rhus tripartitum (Ucria) Grande and Ziziphus lotus (L): effect of water stress. Int J Ecol. https://doi.org/10.1155/2013/819810

Rehm E, Fricke E, Bender J, Savige J (1894) Rogers H (2019) Animal movement driver's variation in seed dispersal distance in a plant-animal network. Proc R Soc B 286:20182007

Rehm E, Fricke E, Bender J, Savige J (1894) Rogers H (2019) Animal movement drives variation in seed dispersal distance in a plant-animal network. Proc R Soc B 286:20182007. https://doi.org/10.1098/rspb.2018.2007

Retief E, Van Wyk AE (2001) The genus Ehretia (Boraginaceae: Ehretioideae) in southern Africa. Bothalia 31(1):9-23

Rowarth JS, Hampton JG, Hill MJ (2007) New Zealand native seed germination requirements A Review. N Z J Botany 45(3):485-501

Samuels IA, Levey DJ (2005) Effects of gut passage on seed germination: do experiments answer the questions they ask? Funct Ecol 19(2):365-368

Schupp EW (1993) Quantity, quality and the effectiveness of seed dispersal by animals. Vegetatio 107(108):15-29

Schupp EW, Jordano P, Gomez JM (2010) Seed dispersal effectiveness revisited: a conceptual review. New Phytol 188:333-353
Schurr FM, Spiegel O, Steinitz O, Trakhtenbrot A, Tsoar A, Nathan N (2009) Long distance seed dispersal. Annual Plant Rev 38:204-237

Song J, Moon BC, Choi G, Yang S (2018) Morphological identification of Lepidii seu descurainiae semen and adulterant seeds using microscopic analysis. Appl Sci 8:2134

Souza JT, Ferraz EMN, Albuquerque UP, Araujo EL (2014) Does proximity to a mature forest contribute to the seed rain and recovery of an abandoned agriculture area in a semiarid climate. Plant Biol 16(4):748-756

Stiles EW, White DW (1986) Seed deposition patters influence of season, nutrients, and vegetation structure. In: Estrada A, Fleming TH (eds) Frugivores and seed dispersal. Springer, Dordrecht

Strauss SS, Irwin RE (2004) Ecological and evolutionary consequences of multispecies plant-animals interactions. Annu Rev Evol Syst 35:435-466

Thabethe V, Wilson A, Hart LA, Downs CT (2015) Ingestion by an invasive parakeet species reduces germination success of invasive alien plants relative to ingestion by indigenous turaco species in South Africa. Biol Invasions 17:3029-3039

Thomas DSG, Twyman C, Osbahr H, Hewitson B (2007) Adaptation to climate change and variability: farmer responses to intra-seasonal precipitation trends in South Africa. Clim Change 83(3):301-322

Thomson FJ, Moles AT, Auld TD, Kingsford R (2011) Seed dispersal distance is more strongly correlated with plant height than with seed mass. J Ecol 99:1299-1307

Tielbörger K, Prasse R (2009) Do seeds sense each other? Testing for density-dependent germination in desert perennial plants. Oikos 118(5):792-800

Trakhtenbrot A, Nathan R, Perry G, Richardson DM (2005) The importance of long-distance dispersal in biodiversity conservation. Divers Distrib 11:173-181

Traveset A, Riera N, Mas RE (2001) Passage through bird guts causes interspecific differences in seed germination characteristics. Funct Ecol 15:669-675

Tsoar A, Shohami D, Nathan R (2011) A movement ecology approach to study seed dispersal and plant invasion: an overview and application of seed dispersal by fruit bats. In: Richardson DM (ed) Fifty years of invasion ecology: the legacy of Charles Elton. Wiley, Oxford, pp 103-119

Turkington R, Goldberg DE, Olsvig-Whittaker L, Dyer AR (2005) Effects of density on timing of emergence and its consequences for survival and growth in two communities of annual plants. J Arid Environ 61:377-396

Ulian T, Flores C, Lira R, Mamatsharaga A, Mogotsi KK, Muthoka P, Ngwako S, Nyamongo DO, Omondi W, Sanogo AK, Sanogo S, Mattana E (2019) Wild plants for a sustainable future. In: Ulian T, Flores C, Lira R, Mamatsharaga A, Mogotsi KK, Muthoka P, Ngwako S, Nyamongo DO, Omondi W, Sanogo AK, Sanogo S, Mattana E (eds) 110 Multipurpose species. Kew, Richmond

Van Der Walt K, Witkowski EFT (2017) Seed viability, germination and seedling emergence of the critically endangered stem succulent, Adenuim swazicum, in South Africa. S Afr J Bot 109:237-245

Van Wyk B, Van Wyk P (2013) Field guide to trees of Southern Africa, 2nd edn. Struik Nature, Cape Town

Vander Wall SB, Beck MJ (2012) A comparison of frugivory and scatter hoarding seed-dispersal syndromes. Bot Rev 78:10-31

Vander Wall SB, Kuhn MK, Gworek JR (2005) Two-phase seed dispersal: linking the effects of frugivorous birds and seed-caching rodents. Oecologia $145: 282-287$

Vellend M (2010) Conceptual synthesis in community ecology. Q Rev Biol 85:183-206

Vukeya LR, Mokotjomela TM, Malebo NJ, Oke S (2020) A 40 years' vegetation cover dynamics in the Free State National Botanical Garden, South Africa. 46th Annual conference of the South African Association of Botanists (SAAB) 7-10 Jan 2020 QwaQwa Campus, University of the Free State

Wang BC, Smith TB (2002) Closing the seed dispersal loop. Trends Ecol Evol 17(8):379-386

Wannan BS, Quinn CJ (1990) Pericarp structure and generic affinities in the Anacardiaceae. Bot J Linn Soc 102(3):225-252. https://doi.org/10.1111/j. 1095-8339.1990.tb01878.x

Ward D (2016) The Biology of deserts, 2nd edn. Oxford University Press, Oxford

Weiersbye IM, Witkowski ETF (2002) Seed fate and practical germination methods for 46 perennial species that colonize gold mine tailings and acid mine drainage-polluted soils in the Grassland Biome. In: Seydack AHW, 
Vorster T, Vermeulen WJ, Van Der Merwe IJ (eds). Multiple Use Management of Natural Forests and Savanna Woodlands: Policy Refinements and Scientific Progress III. Proceedings of Natural Forests and Savanna Woodlands Symposium III, Department of Water Affairs and Forestry, Pretoria, pp. 221-255

Westcott DA, Graham DL (2000) Patterns of movement and seed dispersal of a tropical frugivore. Oecologia 122(2):249-257

Wilman V, Campbell EE, Potts AJ, Cowling RM (2014) A mismatch between germination requirements and environmental conditions: Niche conservatism in xeric subtropical thicket canopy species? S Afr J Bot 92:1-6
Zietsman PC, Botha FC (1987) Seed germination of Ziziphus mucronata subsp. mucronata. S Afr J Bot 53(5):341-344

Zietsman PC, Van Wyk AE, Botha FC (1989) Vegetative and reproductive phenology of Ziziphus mucronata subsp. mucronata (Rhamnaceae). S Afr J Bot 55(6):564-573

\section{Publisher's Note}

Springer Nature remains neutral with regard to jurisdictional claims in published maps and institutional affiliations.

\section{Submit your manuscript to a SpringerOpen ${ }^{\circ}$ journal and benefit from:}

- Convenient online submission

- Rigorous peer review

- Open access: articles freely available online

- High visibility within the field

- Retaining the copyright to your article

Submit your next manuscript at $\boldsymbol{\nabla}$ springeropen.com 